\title{
Evaluasi Daya Dukung Tanah Lunak Hasil Stabilisasi Kimia dengan Terra Firma di Daerah Gedebage, Kota Bandung, Provinsi Jawa Barat
}

\author{
BAYU ARIFIANTO, BENNY MOESTOFA \\ Jurusan Teknik Sipil, Institut Teknologi Nasional \\ Email: bay.arifianto@gmail.com
}

\begin{abstract}
ABSTRAK
Tanah lempung lunak adalah salah satu jenis tanah dasar yang sering menyebabkan masalah dalam berbagai jenis konstruksi karena daya dukungnya rendah dan kepekaan terhadap perubahan kadar air cukup tinggi. Oleh karena itu, perlu dilakukan perbaikan tanah dasar menggunakan bahan kimia Terra Firma untuk meningkatkan daya dukung tanah dasarnya. Penelitian ini dilaksanakan dengan pengambilan sampel dari Proyek Summarecon di Gedebage, Kota Bandung, termasuk pengujian skala laboratorium, untuk menentukan sifat fisik dan mekanik tanah lempung lunak. Uji skala laboratorium telah dilaksanakan pada berbagai variasi campuran tanah dengan komposisi Terra Firma 3\%, 6\%, dan 9\%. Berdasarkan hasil uji laboratorium diperoleh nilai CBR tanah dasar sebesar 2,7\% dan UCS 2,02 kg/ $\mathrm{cm}^{2}$, sedangkan hasil pengujian menunjukkan bahwa campuran Terra Firma yang paling efektif adalah 6\% dengan waktu pemeraman selama 21 hari, dimana nilai CBR yang diperoleh sebesar 37,28\% dan UCS 9,66 kg/ $\mathrm{cm}^{2}$. Oleh karena itu dapat disimpulkan bahwa penggunaan stabilisasi kimia Terra Firma dapat meningkatkan daya dukung tanah lempung lunak hingga 14 kali.
\end{abstract}

Kata kunci: tanah lempung lunak, daya dukung, stabilisasi kimia, Terra Firma.

\begin{abstract}
Soft clay soil is one of the basic types of soil that often causes problems in any kinds of construction due to its low bearing capacity and high sensitivity to changes in moisture content. Therefore, the soil needs to be repaired by applying Terra Firma chemicals to increase the bearing capacity of the soil. This research is conducted by taking soil samples from the Summarecon Gedebage Project area, Bandung City, and was conducted laboratory scale testing, to determine the physical and mechanical properties of soft clay soil. The laboratory scale test was conducted with various variations of ground mixture with Terra Firma 3\%, 6\%, and $9 \%$. Based on laboratory test results it is found that the base soil CBR value is $2.7 \%$ and UCS $2.02 \mathrm{~kg} / \mathrm{cm}^{2}$, while the applied Terra Firma chemicals comparison result shows that the $6 \%$ mixture is the most effective with 21 days curing time, CBR value of $37.28 \%$ and UCS $9.66 \mathrm{~kg} / \mathrm{cm}^{2}$. Therefore it can be concluded that the use of Terra Firma chemicals can increase the bearing capacity of soft clay soil up to 14 times.
\end{abstract}

Keywords: soft clay soil, bearing capacity, chemical stabilization, Terra Firma. 


\section{PENDAHULUAN}

Indonesia merupakan negara berkembang, secara umum menurut World Economic Forum (WEF) tahun 2017, saat ini negara berkembang menunjukkan peningkatan pembangunan, pemerataan dan keadilan bagi masyarakat diseluruh wilayah Indonesia, salah satu upaya yang sedang dilakukan oleh pemerintah Kota Bandung adalah pengembangan kawasan Gedebage, yaitu dengan adanya proyek pembangunan Summarecon Gedebage, di wilayah Bandung Timur, Kota Bandung, Provinsi Jawa Barat. Dengan adanya pengembangan wilayah dan pembangunan konstruksi di daerah tersebut, maka akan bertambahnya jaringan jalan atau meningkatkan jaringan jalan yang sudah ada, baik kelas jalan maupun kapasitasnya untuk mengatasi tingkat kepadatan lalu lintas yang akan terjadi dan melancarkan konektivitas jalan dalam rangka terwujudnya pengembangan dan pembangunan di wilayah tersebut. Secara garis besar setiap pembangunan konstruksi jalan senantiasa melewati tanah dasar dengan daya dukung rendah seperti dijumpai pada studi kasus yang terjadi di Gedebage, dengan tanah dasar berupa tanah lempung lunak. Oleh karena itu diperlukan perbaikan tanah dasar dengan cara distabilisasi kimia dengan Terra Firma, untuk meningkatkan kapasitas daya dukung konstruksi jalan pada Kawasan tersebut. Lokasi penelitian dalam Tugas Akhir ini dapat dilihat pada Gambar 1.

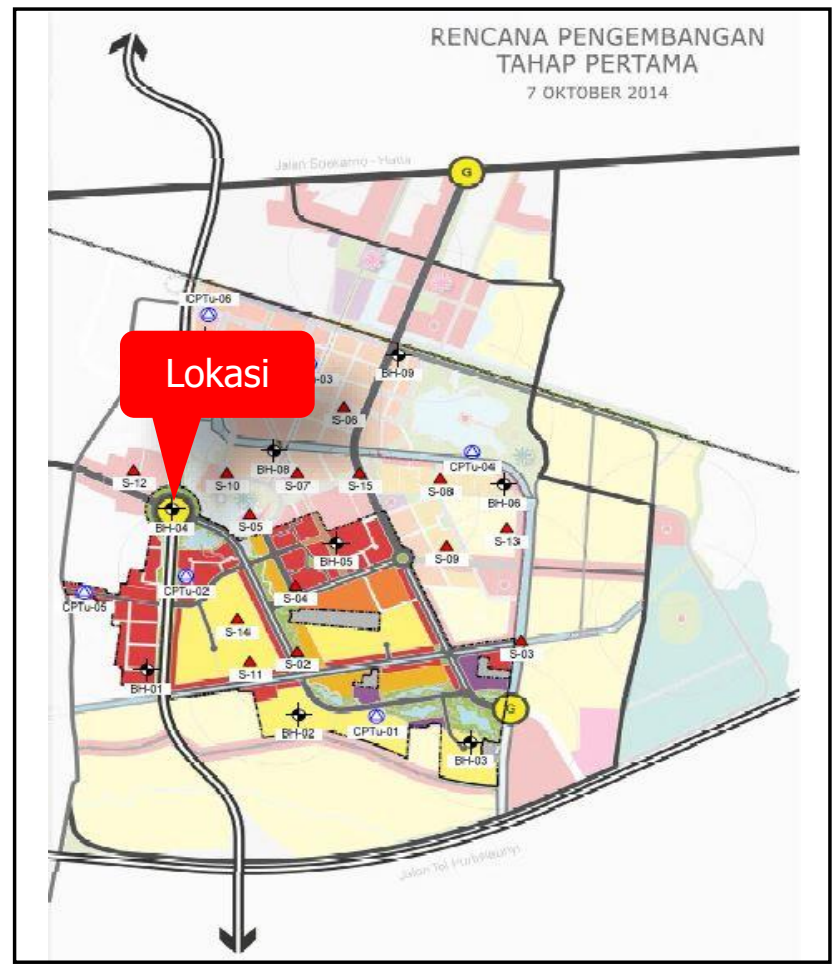

Gambar 1. Daerah penelitian di Proyek Summarecon Gedebage

(Sumber: Summarecon, 2015)

\section{TINJAUAN PUSTAKA}

\subsection{Umum}

Tanah dalam pandangan Teknik Sipil adalah himpunan mineral, bahan organik dan endapanendapan yang relative lepas (loose) yang terletak di atas batu dasar (bedrock) (Hardiyatmo, 2002). Tanah didefinisikan sebagai material yang terdiri dari agregat (butiran) padat yang tersementasi satu sama lain dan dari bahan-bahan organik hasil pelapukan batuan dasar terdiri dari, udara, air dan butir, yang mengisi ruang-ruang kosong diantara partikel-partikel padat tersebut (Das, 1995). 


\subsection{Kondisi Geologi Regional}

Berdasarkan Peta Geologi Regional Lembar Bandung, Jawa Barat, skala 1 : 100.000 oleh Silitonga (2003), menunjukan bahwa kondisi tanah yang ada didaerah Gedebage, khususnya di proyek Summarecon Gedebage, merupakan tanah hasil endapan danau dengan kedalaman (0-125 m), berupa lempung lunak (Ql). Peta Geologi Regional Lembar Bandung, Jawa Barat dapat dilihat pada Gambar 2.

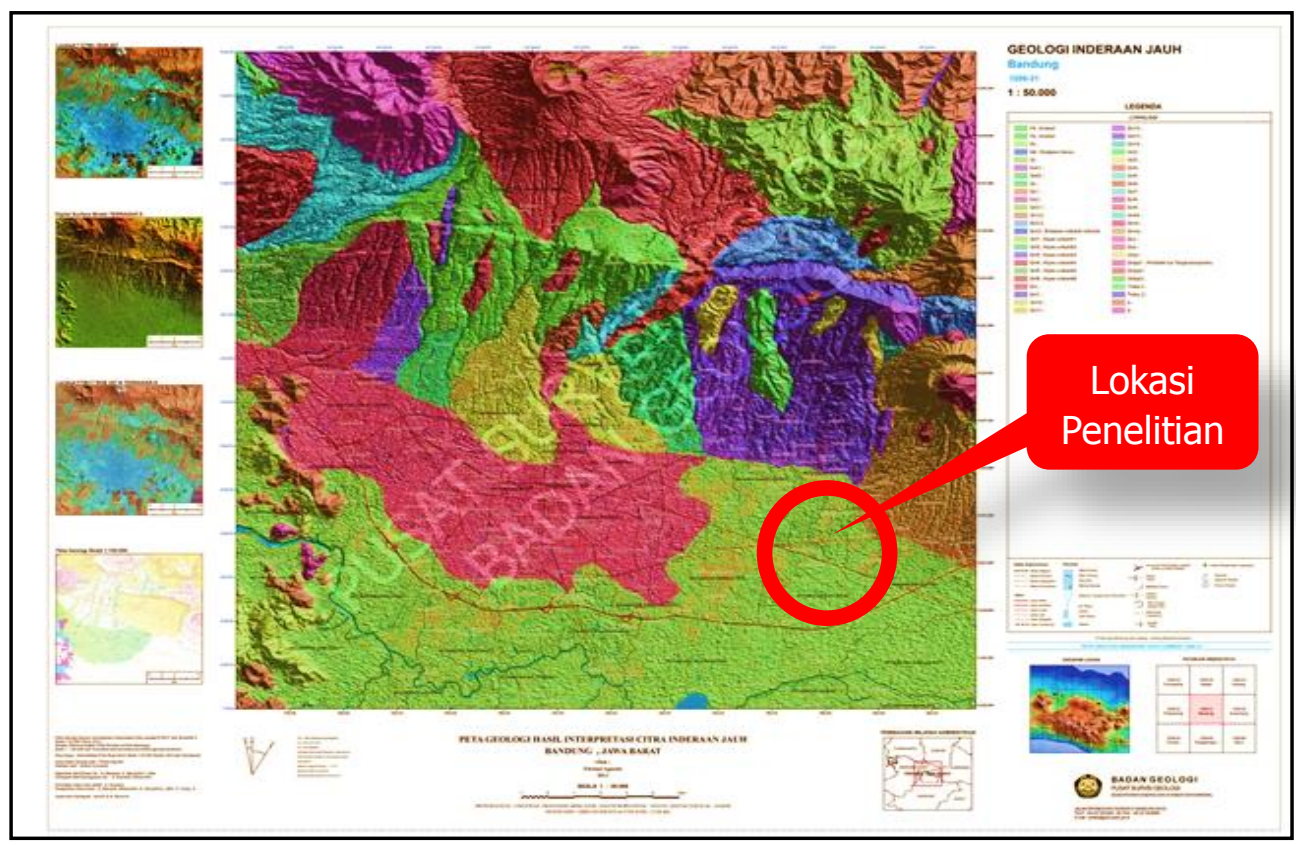

Gambar 2. Peta regional lembar Jawa Barat skala 1 : 100.000 (Sumber: Silitonga P.H, 2003)

\subsection{Tanah Lunak}

Tanah lunak dalam konstruksi seringkali menimbulkan permasalahan, baik stabilitas maupun penurunan, akibat rendahnya daya dukung. Daya dukung yang rendah dapat menyebabkan kerugian, baik dari sisi biaya konstruksi yang semakin mahal, serta kemungkinan besar gangguan stabilitas konstruksi di atasnya. Untuk menanggulangi permasalahan tersebut, maka diperlukan pekerjaan perbaikan tanah dengan stabilisasi kimia.

\subsection{Stabilisasi Tanah}

Stabilisasi tanah adalah pencampuran tanah dengan bahan tertentu guna memperbaiki sifatsifat teknis, tepatnya meningkatkan daya dukung, memperkecil kompressibilitas, serta untuk mencegah terjadinya potensi pengembangan dan kepekaan terhadap perubahan kadar air akibat tingginya sensitivitas tanah. Proses perbaikan tanah dapat dilakukan dengan cara penanganan antara lain seperti pemadatan ataupun dengan pencampuran tanah menggunakan semen, kapur, abu terbang, injeksi semen (grouting), dan stabilisasi kimia dengan Terra Firma.

\subsection{Terra Firma}

Terra Firma adalah bahan kimia berupa serbuk yang digunakan untuk stabilisasi tanah, berwarna coklat dan terdiri dari senyawa berbasis resin polimer semen, yang dicampur dengan serat. Terra Firma dapat mengikat dengan cepat dan memperkuat tanah yang ada, dengan memberikan fleksibilitas yang cukup pada tanah dasar, sehingga jalan tidak mengalami retak. Proses kimia yang terjadi pada saat pencampuran seperti sementasi, hidrasi, pertukaran ion, oksidasi, polimerisasi presipitasi, flokulasi dan karbonasi dan lain-lain. (sumber: CRRI, New Delhi. Report on Evaluation of "Terra Firma" as Stabiliser for Road Pavement Layers, 2016). 


\section{METODOLOGI PENELITIAN}

\subsection{Bagan Alir Metodologi Penelitian}

Untuk memberikan gambaran yang jelas tentang tahapan kegiatan penelitian yang dilakukan, maka dapat dilihat bagan alir penelitian pada Gambar 3 di bawah ini.

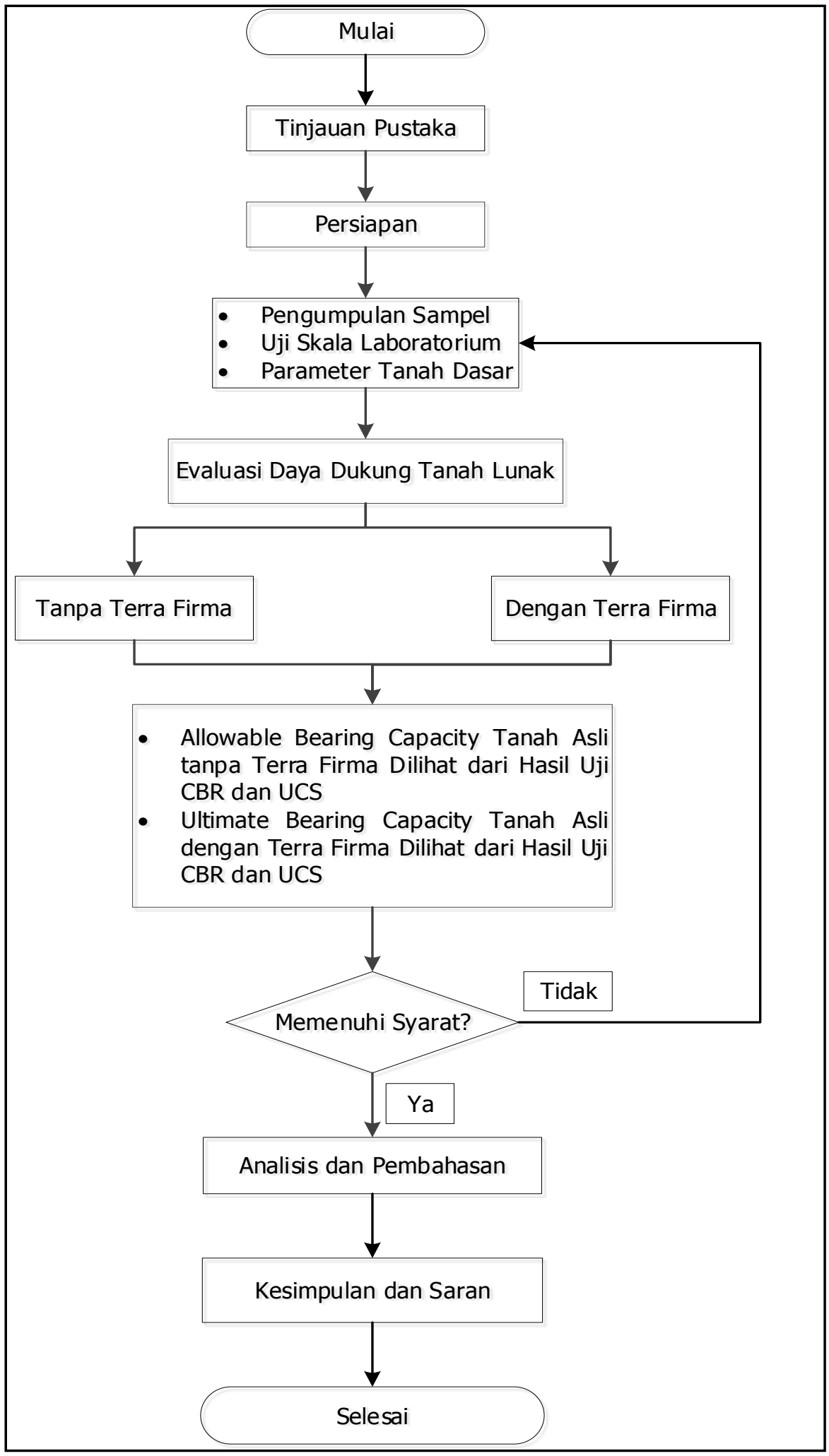

Gambar 3. Bagan alir penelitian 
Evaluasi Daya Dukung Tanah Lunak Hasil Stabilisasi Kimia dengan Terra Firma di Daerah Gedebage, Kota Bandung, Provinsi Jawa Barat

\section{ANALISIS DAN PEMBAHASAN}

\subsection{Hasil Uji Laboratorium}

Sampel tanah yang akan diuji berupa tanah lempung abu-abu dari lokasi Proyek Summarecon Gedebage, Bandung, telah diuji sifat fisik dan sifat mekaniknya, berikut hasil pengujian laboratorium ditunjukkan pada Tabel 1 berikut.

Tabel 1. Hasil Pengujian Laboratorium Tanah Asli dan Tanah telah Distabilisasi

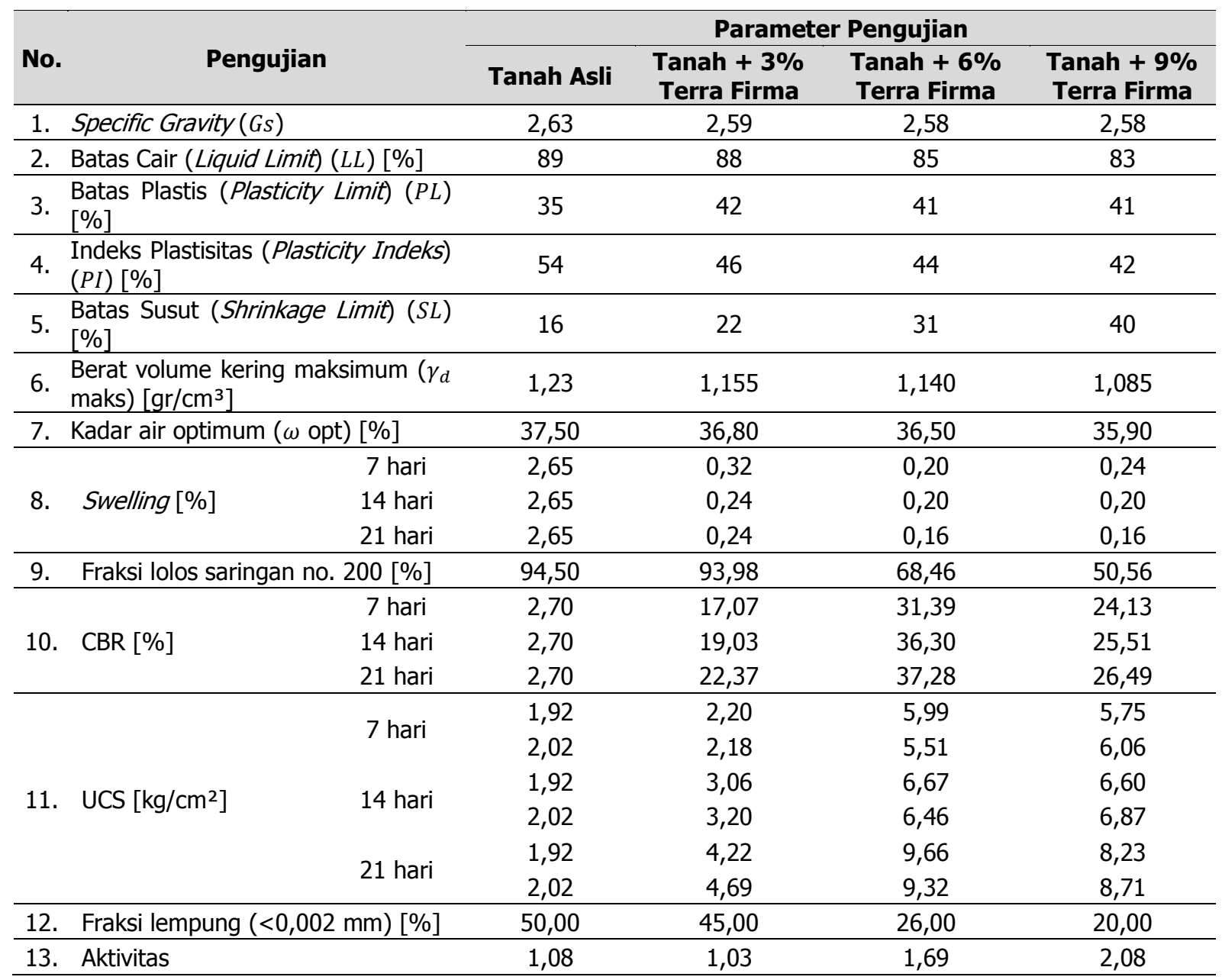

Dari data yang diperoleh dari hasil pengujian laboratorium menunjukkan beberapa kenaikan dan penurunan disetiap jenis pengujian yang dilakukan, kenaikan dan penurunan yang terjadi ini akibat pengaruh dari bahan stabilisasi yang digunakan, dimana Terra Firma itu sendiri merupakan bahan kimia berupa serbuk yang terdiri dari resin polimer semen dan terdapat serat-serat. Untuk mengetahui kekuatan tanah yang belum distabilisasi dan tanah yang sudah distabilisasi, maka dilakukan pengujian CBR (California Bearing Ratio) dan UCS (Unconfined Compression Strength). Pengujian CBR dilakukan dengan masa pemeraman selama 7 hari, 14 hari dan 21 hari serta direndam 4 hari (soaked), dimana pada kondisi ini adalah bertujuan untuk mengetahui daya dukung tanah pada saat tanah dalam kondisi yang paling buruk, sedangkan pengujian UCS dilakukan dengan masa pemeraman 7 hari, 14 hari dan 21 hari tanpa perendaman. 


\subsection{Pembahasan}

Penelitian ini akan membahas karakteristik dan daya dukung tanah setelah distabilisasi berupa sifat fisik dan sifat mekanik tanah. Sifat fisik meliputi pengujian specific gravity, batas-batas konsistensi (Atteberg Limit), berat volume kering maksimum, kadar air optimum dan analisis gradasi butiran. Sifat mekanik berupa CBR soaked, pengembangan (swelling), dan UCS.

\subsubsection{Pengaruh Bahan Stabilisasi Terhadap Batas-Batas Konsistensi Tanah}

Nilai batas-batas konsistensi juga mengalami perubahan seiring penambahan variasi bahan stabilisasi, hasil perubahan dapat dilihat pada Gambar $\mathbf{4}$ berikut.

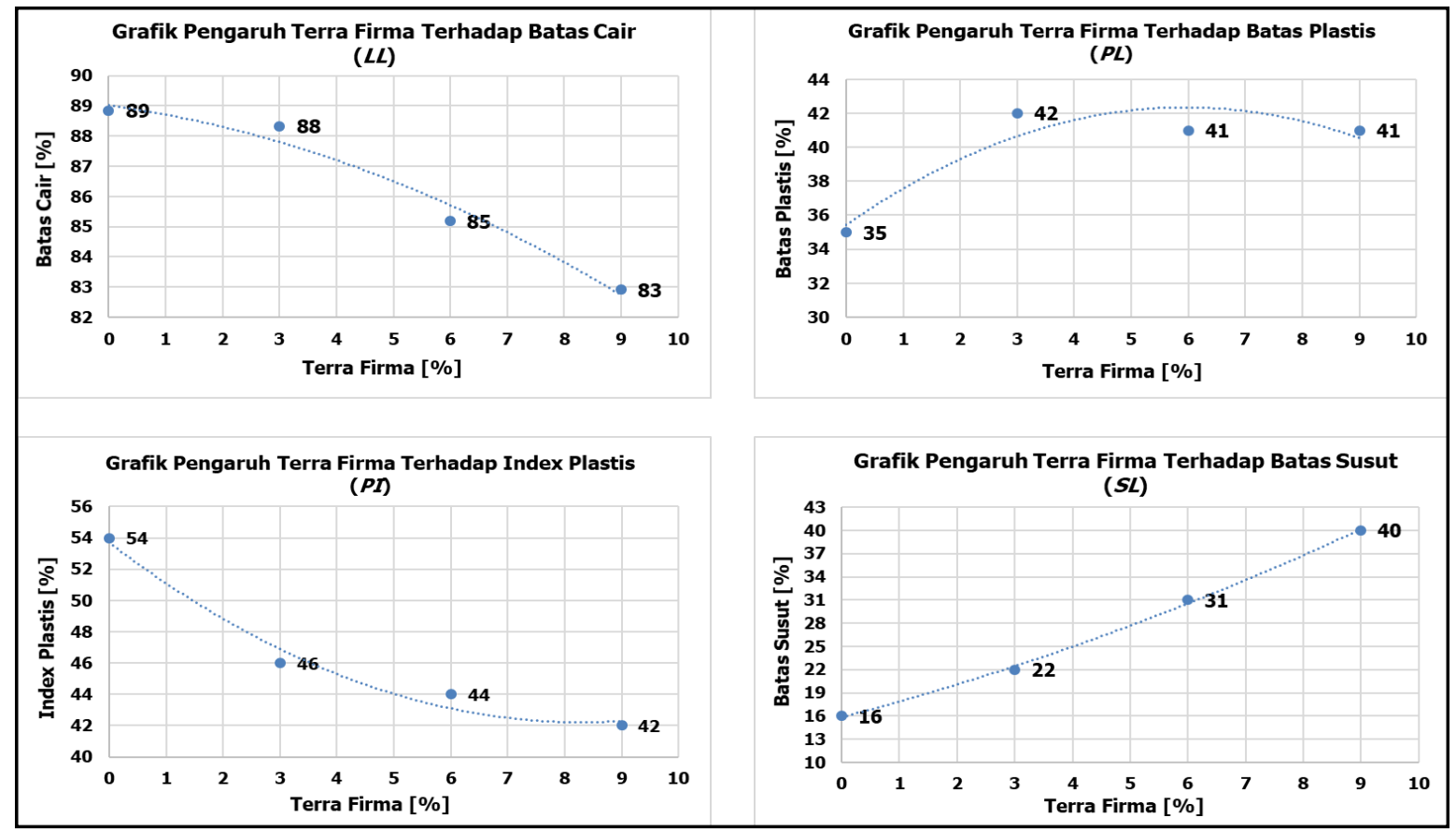

Gambar 4. Pengaruh bahan stabiliasi terhadap batas-batas konsistensi tanah

\subsubsection{Pengaruh Bahan Stabilisasi Terhadap Karakteristik Tanah}

Pengaruh bahan stabiliasi terhadap karakteristik tanah asli dan tanah setelah distabiliasi, dapat dilihat dari klasifikasi menurut AASHTO dan USCS, seperti berikut ini:

\section{a. Karakteristik Tanah Berdasarkan Klasifikasi AASHTO}

Berdasarkan hasil uji skala laboratorium, akan diperoleh karakteristik tanah asli dan tanah setelah distabilisasi berdasarkan klasifikasi AASHTO, seperti pada Gambar $\mathbf{5}$.

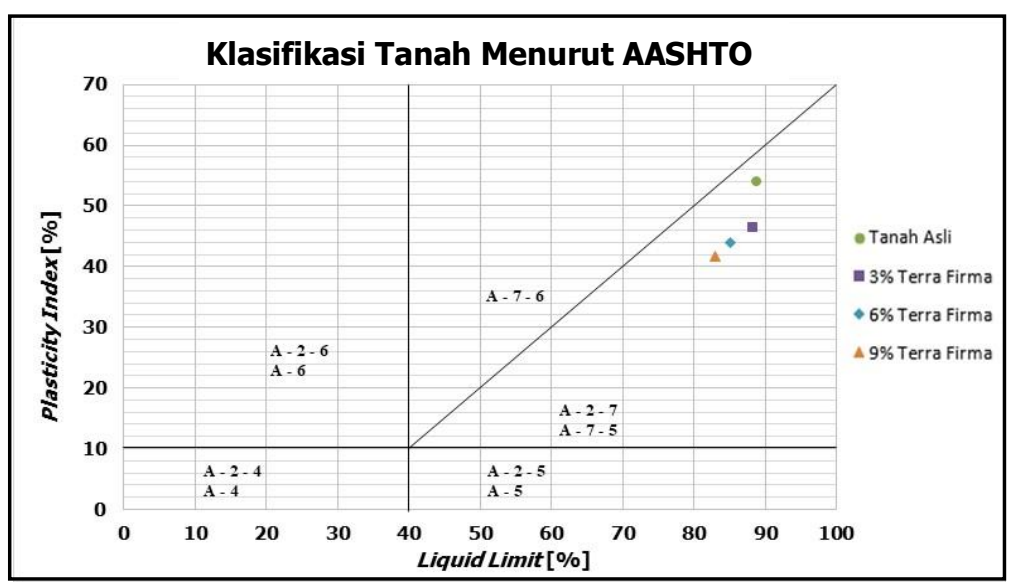

Gambar 5. Grafik karakteristik tanah berdasarkan klasifikasi AASHTO 


\section{b. Karakteristik Tanah Berdasarkan Klasifikasi USCS}

Berdasarkan hasil uji skala laboratorium, akan diperoleh karakteristik tanah asli dan tanah setelah distabilisasi berdasarkan klasifikasi USCS, seperti pada Gambar 6.

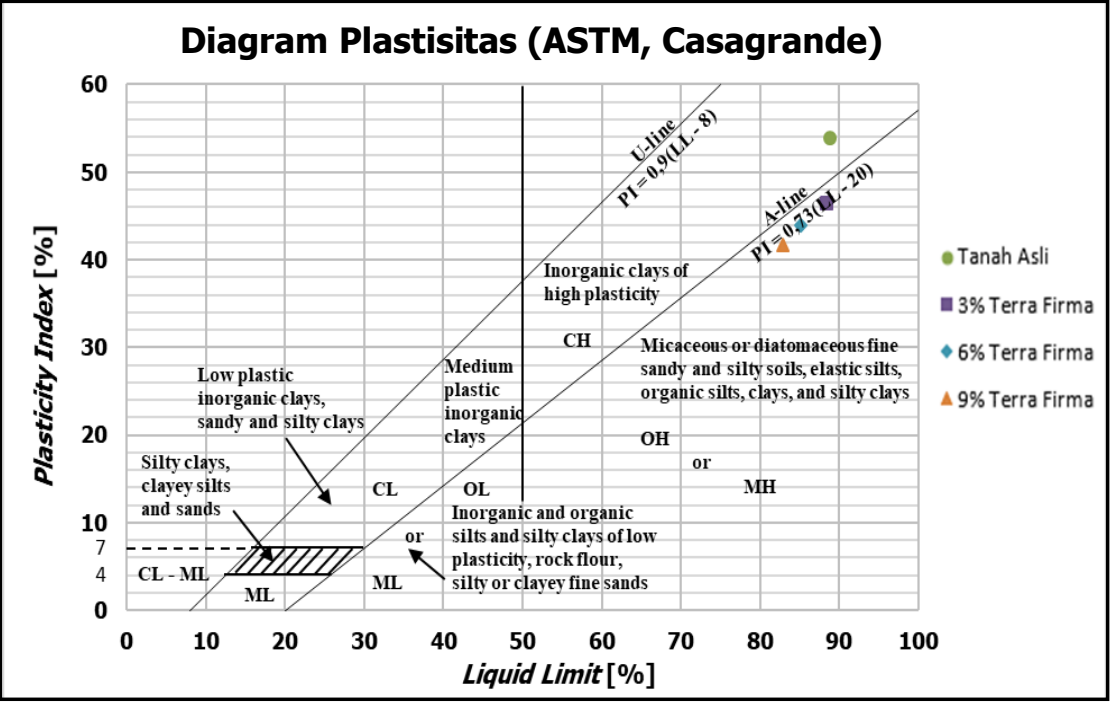

Gambar 6. Grafik karakteristik tanah berdasarkan klasifikasi USCS

\subsubsection{Pengaruh Bahan Stabilisasi Terhadap Specific Gravity Tanah}

Nilai specific gravity mengalami perubahan terhadap penambahan bahan stabilisasi. Nilai dari tiap kadar stabilisasi dapat dilihat pada Gambar 7 berikut.

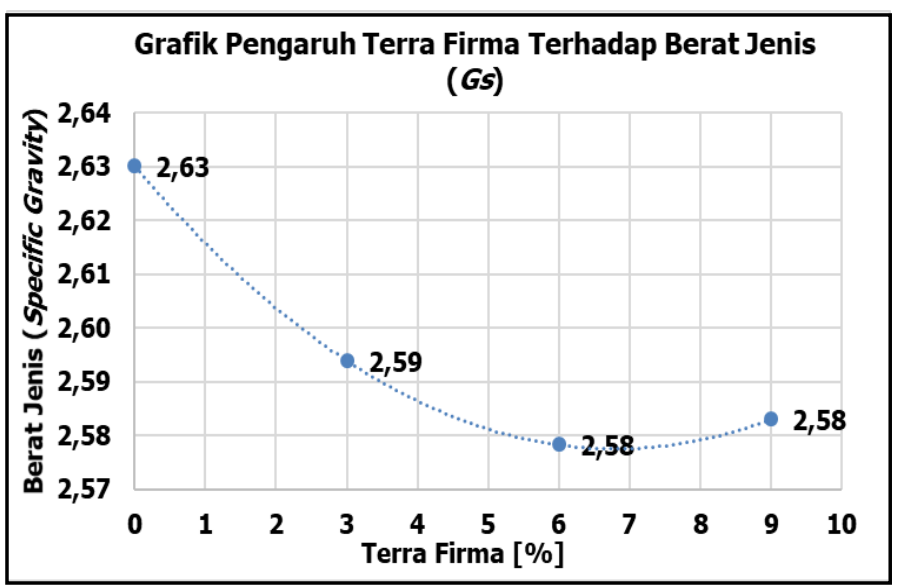

Gambar 7. Spesific gravity tanah asli dan tanah stabilisasi

\subsubsection{Pengaruh Bahan Stabilisasi Terhadap Nilai Aktivitas Tanah}

Nilai aktivitas tanah dapat diketahui berdasarkan hasil uji batas-batas konsistensi dan uji distribusi ukuran butir. Hasil yang didapat selanjutnya diplot kedalam grafik potensi pengembangan menurut Seed et al. (1962), seperti yang terlihat dalam Gambar 8. 


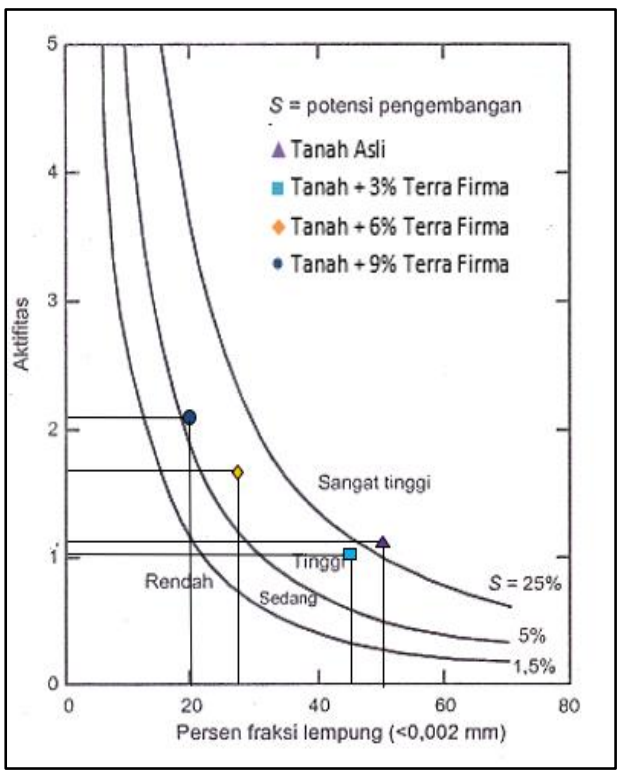

Gambar 8. Diagram klasifikasi potensi pengembangan tanah yang distabilisasi (Sumber: Seed et al., 1962 dalam Hardiyatmo, 2002 Hal. 122)

\subsubsection{Pengaruh Bahan Stabilisasi Terhadap Pengembangan (Swelling) Tanah}

Tanah yang distabilisasi menggunakan Terra Firma akan mengalami proses pengikatan sewaktu proses pemeraman, proses tersebut mengubah tingkat kekerasan dan kepadatan tanah. Semakin lama waktu yang dibutuhkan maka kekuatan tanah akan lebih tinggi serta tanah akan lebih padat, sehingga nilai swelling yang didapatkan akan lebih kecil. Hal tersebut dapat dilihat pada Gambar 9 berikut.

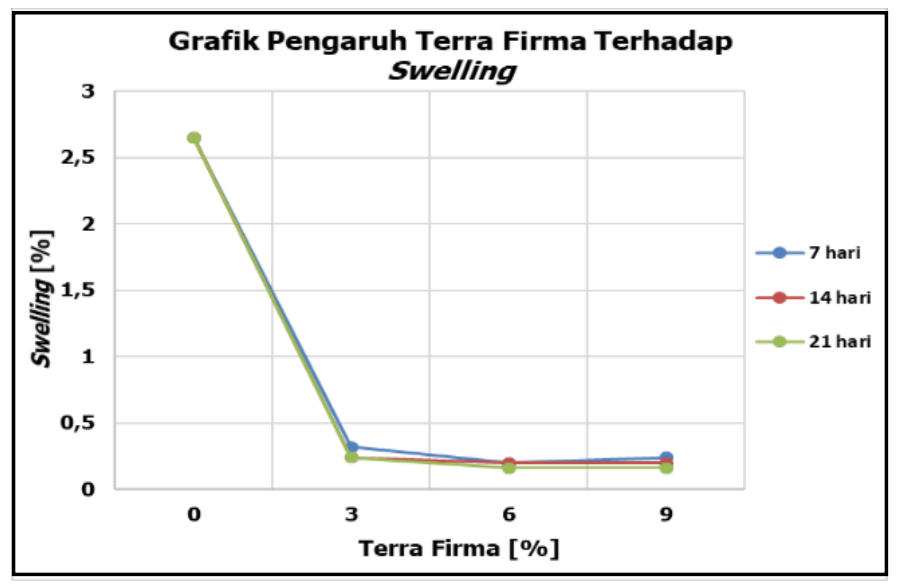

Gambar 9. Nilai pengembangan (swelling) tanah asli dan tanah stabilisasi

\subsubsection{Pengaruh Bahan Stabilisasi Terhadap CBR Tanah}

Nilai daya dukung tanah dapat ditinjau salah satunya dari pengujian California Bearing Ratio (CBR). Pengujian ini menggunakan jenis pengujian CBR soaked dengan variasi waktu pemeraman 7 hari, 14 hari, dan 21 hari, dengan perendaman benda uji selama 4 hari. Hasil pengujian CBR dapat dilihat pada Gambar 10 berikut. 
Evaluasi Daya Dukung Tanah Lunak Hasil Stabilisasi Kimia dengan Terra Firma di Daerah Gedebage, Kota Bandung, Provinsi Jawa Barat

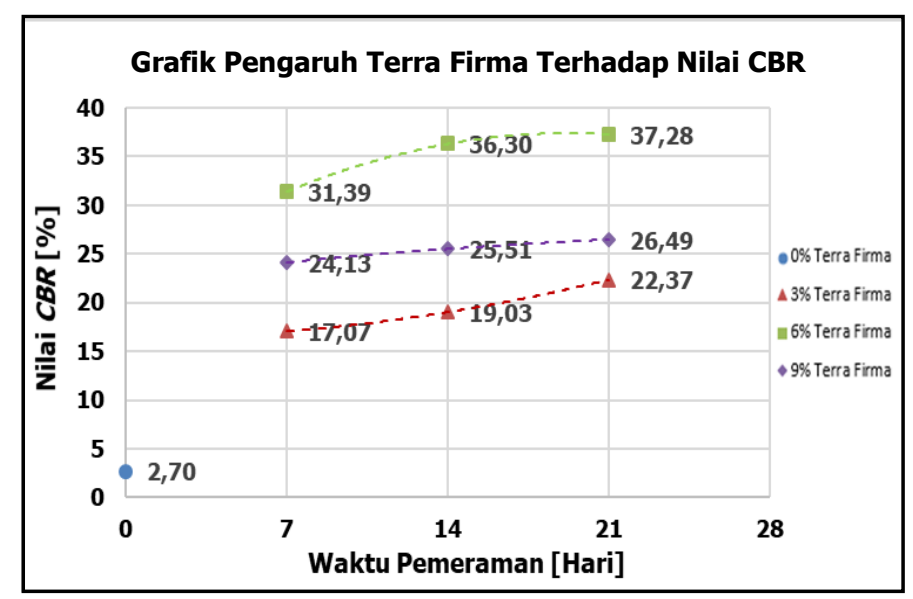

Gambar 10. CBR tanah asli dan tanah yang telah distabilisasi

\subsubsection{Pengaruh Bahan Stabilisasi Terhadap UCS Tanah}

Pengujian Unconfined Compression Strength (UCS) pada penelitian ini dilakukan untuk mengetahui besarnya kekuatan geser tanah terhadap pembebanan langsung yang diberikan pada sampel tanah. Penelitian ini menggunakan variasi pemeraman selama 7 hari, 14 hari, dan 21 hari. Hasil pengujian dapat dilihat pada Gambar 11 berikut.

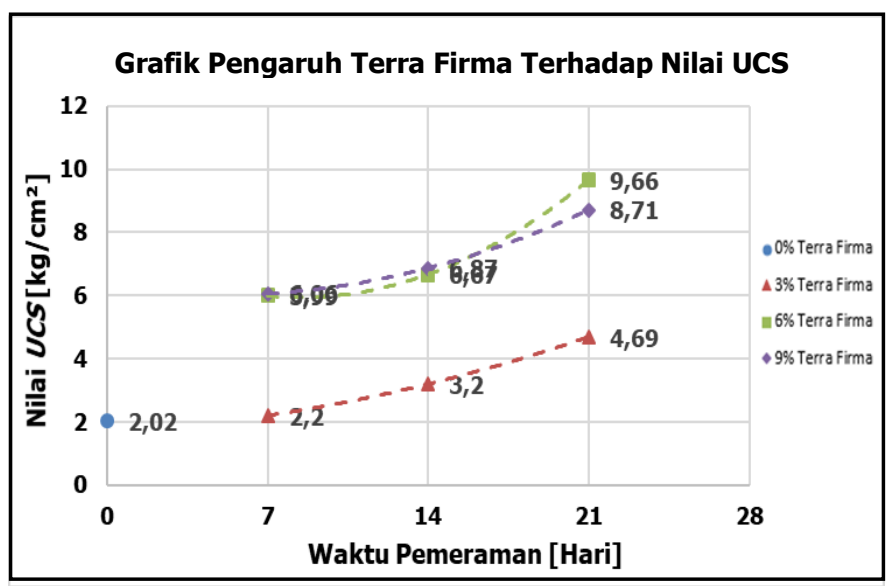

\section{Gambar 11. UCS tanah asli dan tanah yang telah distabilisasi}

Selain untuk mengetahui daya dukung dari tanah asli dan tanah setelah distabiliasi, nilai tegangan dan regangan dari pengujian UCS juga dapat menentukan karakteristik dari tanah asli dan tanah setelah distabiliasi. Batasan karakteristik tanah dan hasil plot data teganganregangan dari pengujian UCS ditampilkan pada Gambar 12 berikut. 
Bayu Arifianto, Benny Moestofa

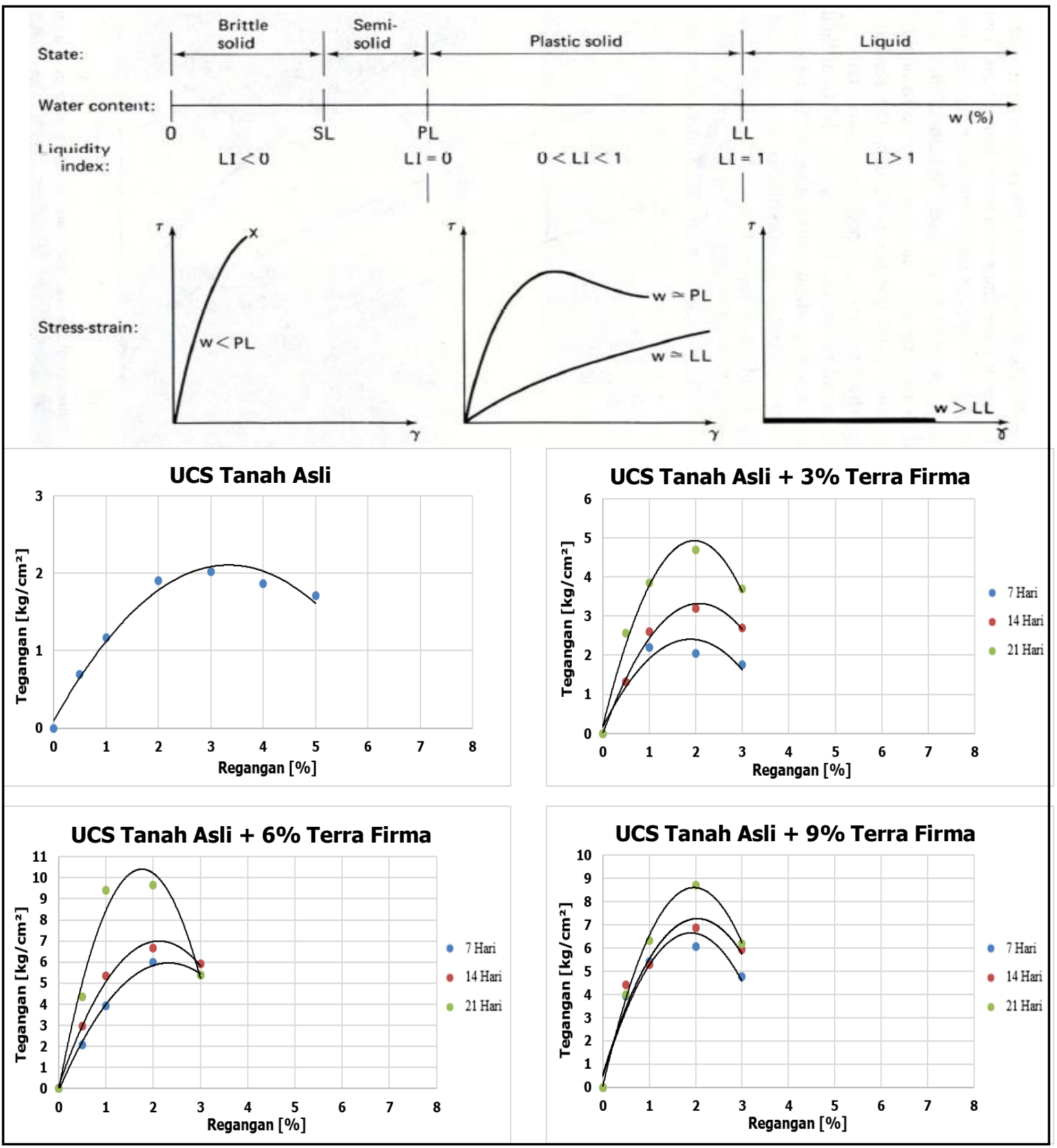

Gambar 12. Grafik karakteristik tanah dari nilai UCS (tegangan-regangan)

\section{KESIMPULAN}

Berdasarkan analisis dan pembahasan, maka dapat dibuat perihal kesimpulan yang dapat diuraikan sebagai berikut:

1. Tanah lempung lunak pada lokasi penelitian, menurut klasifikasi AASHTO termasuk dalam kategori A-7-5 untuk tanah asli dan setelah distabilisasi, merupakan tipe material yang paling dominan tanah lempung dengan penilaian sebagai bahan tanah dasar baik sampai buruk. Sedangkan menurut klasifikasi USCS, tanah asli merupakan lempung anorganik dengan plastisitas tinggi Clay High Plasticity $(\mathrm{CH})$ dimana $(L L>50)$, sedangkan tanah yang sudah distabilisasi merupakan lempung organik dengan plastisitas tinggi $\mathrm{OH}$ dimana $(L L>50)$.

2. Sifat fisik yang dilakukan terhadap tanah asli dan tanah yang sudah distabilisasi mengalami penurunan. Sedangkan sifat mekanik mengalami peningkatan. 
3. Hasil klasifikasi tanah menurut AASHTO dan USCS menunjukkan bahwa tanah asli dan tanah yang telah distabilisasi merupakan tanah yang memiliki sifat plastisitas tinggi, akan tetapi dari grafik aktivitas dan hasil uji pengembangan menunjukkan penurunan potensi pengembangan.

4. Penggunaan bahan kimia Terra Firma yang efektif dalam meningkatkan daya dukung tanah dilihat dari hasil uji CBR dan UCS, ada pada campuran tanah asli $+6 \%$ Terra Firma, dengan waktu pemeraman 21 hari.

\section{DAFTAR RUJUKAN}

CRRI. (2016). Evaluation of "Terra Firma" as Stabiliser for Road Pavement Layers. New Delhi: CSIR-Central Road Research Institue.

Das, B. M. (1995). Mekanika Tanah (Prinsip-Prinsip Rekayasa Geoteknik) Jilid 1. Jakarta: Erlangga.

Hardiyatmo, H. (2002). Mekanika Tanah I. $5^{\text {th }}$ Ed. Yogyakarta: Gadjah Mada University Press. Seed et al. (1962). Prediction of Swelling Potential for Compacted Clays. Journal of The Soil Mechanics and Foundations Division, 88(3), 53-88.

Silitonga, P. H. (2016, Oktober 12). Geologi Indonesia. Dipetik Agustus 20, 2018, dari Pemetaan Pusat Survei Geologi: https://psg.bgl.esdm.go.id/geomap/

Summarecon. (2015). Laporan Penyelidikan Tanah. Bandung: Summarecon Bandung. 